\title{
Protective effect of Acampe praemorsa (Roxb.) Blatt. \& McCann against oxidative stress
}

\author{
U Praveen Kumar ${ }^{1 .}$, GSN Koteswara Rao ${ }^{1}$, A Rajasekhar Reddy ${ }^{1}, \mathrm{~K}_{\text {Umasankar }}{ }^{1}$ \& Y Vangoori ${ }^{2}$ \\ ${ }^{1} \mathrm{~K}$ L College of Pharmacy, Koneru Lakshmaiah Education Foundation, Vaddeswaram, Guntur, Andhra Pradesh, 522 502, India \\ ${ }^{2}$ Department of Pharmacology, Santhiram Medical College \& General Hospital, Nandyal, Andhra Pradesh, India \\ *Email: Praveen.chintu32@gmail.com
}

\section{ARTICLE HISTORY}

Received: 12April 2021

Accepted: 21 May 2021

Available online: 01 July 2021

KEYWORDS

Antioxidants

Extracts

Free radicals

Oxidative stress

Phytochemicals

\section{ABSTRACT}

The current study was carried to make available phytochemical information and evaluation of antioxidant activity of Acampe praemorsa (Roxb.) Blatt. \& McCann. The phytochemical analysis was carried out using procedures and quantified phenolic and alkaloid contents. The antioxidant activity was evaluated by in-vitro and in-vivo studies. The In-vitro antioxidant activity was carried on free radicals such as superoxide, hydroxyl DPPH, hydrogen peroxide, evaluation of reducing power. In-vivo study was carried on albino Wistar rats with different doses of extracts. The results provide that, A. praemorsa extracts have diversified phytochemicals in extracts like steroids, alkaloids, phenolics, glycosides, oils, quinones, tannins etc. The hydroalcoholic extract has more phenolic $(26.80 \pm 0.51)$ and alkaloid $(20.59 \pm 0.22)$ contents. The antioxidant activity results provide information that the extracts possess concentration dependent activity on tested free radicals. The hydroalcoholic extract has more protective nature against superoxide, $\mathrm{DPPH}, \mathrm{H}_{2} \mathrm{O}_{2}$ free radicals and reducing power but ethyl acetate extract has more potential against hydroxyl free radical than hydroalcoholic extract. The extracts were found to be safe on toxic studies and In-vivo study results and they play significant role in controlling the oxidative enzymes such as catalase, superoxide dismutase, lipid peroxidation (malonaldehyde) in the body. Thus, it was determined that A. praemorsa have potential bioactive compounds and antioxidant activity.

\section{Introduction}

Now a days, there has been an upsurge of new disease and diverse side effects due to enduring usage of current drugs increasing the interest on evaluation of new therapeutic agents (1). The diseases are mainly affecting functions of different body organs and finally cause mortality (2). The impairment of body organs can lead to imbalance in their actual mechanisms including production of antioxidants (3, 4). The different previous reports explain that maximum diseases source for the over production of oxidants in the body $(5,6)$. The over production of oxidants can lead to oxidative stress, encompass in progression and development of different diseases like diabetes mellitus, Alzheimer's disease, neurodegenerative disorders, atherosclerosis, arthritis etc (7). The balance between oxidant and antioxidant can increase by providing the external antioxidant as supplements and providing the medications to control oxidants and disease-causing agents in the body $(8,9)$.

As earlier said, identification of new drugs from different natural resources got more attentive research around the world and it is primarily from medicinal plants (10). As, the emerging of new diseases and getting resistance to current day using medicines, the researchers and pharmaceutical industries are concentrating on new drugs from plants and their derivatives (11). In recent decades, many bioactive molecules have been reported from medicinal plants around the world to treat different diseases including oxidative stress $(12,13)$. The discovered medicinal plants have also been used as food supplements to enhance the antioxidants in the body (14). But still, there were many medicinal plants available and not reported scientifically about their medicinal values. Acampe praemorsa (Roxb.) Blatt. \& McCann (The small warty acampe) is one of such medicinal plants belonging to the family Orchidaceae. Very few researches reported on its traditional usage in bone fractures, anti-typhoid and some other reports about the orchids have potential medicinal values like enhancing white blood cells, reducing headache, fatigue etc. (15-19). So, the current study was aimed to provide the phytochemical information and antioxidant activity of $A$. praemorsa. 


\section{Materials and Methods}

\section{Chemicals and Reagents}

The chemicals and reagents used in current study were analytical grade. The diagnostic kits used in study were purchased from Span Diagnostics Ltd, Gujarat, India. The standard drugs Ascorbic acid, Trolox were from Sigma Aldrich Co.

\section{Preparation of Plant Extracts}

The plant material A. praemorsa (Roxb.) Blatt. \& McCann (Voucher specimen number:23342) was collected from Araku valley region, Visakhapatnam and was authenticated by Prof. S. B. Padal, Department of Botany, Andhra Pradesh, India (Fig. 1). The collected aerial parts were cleaned under running tap water to remove debris and was shade dried. The dried material was made as bristly powder. The powder was used for extraction by maceration process successively using ethyl acetate and hydro-alcoholic solution (70\% ethanol in water $\mathrm{v} /$ v). The collected solvents were then evaporated using rotavap and extracts $[A$. praemorsa ethyl acetate extract (APEAE) and A. praemorsa hydro-alcoholic extract (APHAE)] were stored in desiccator for further usage.

\section{Phytochemical Analysis}

The collected extracts were analysed to explore extracts' chemical profile using standard phytochemical tests qualitatively $(20,21)$ and quantitatively quantified the alkaloids and phenolics.

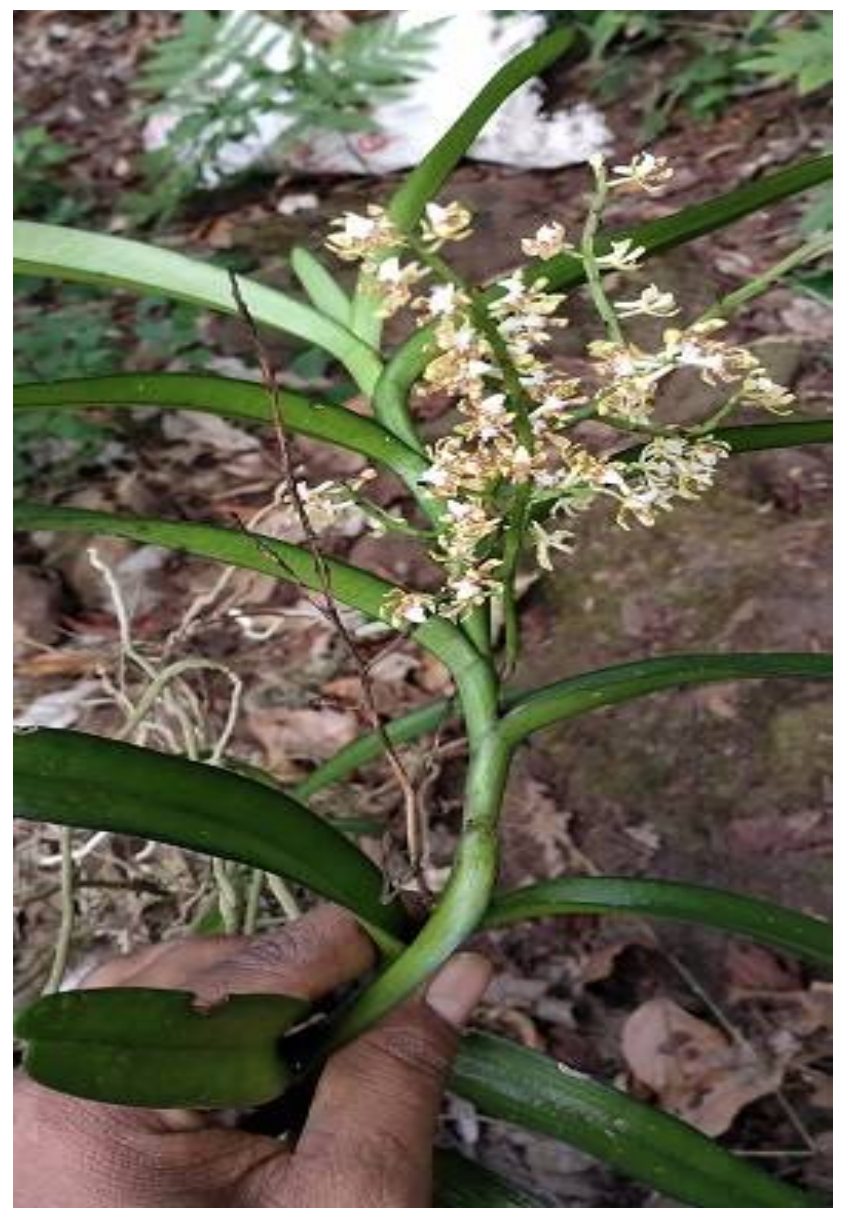

Fig. 1. Acampe praemorsa

\section{Quantification of Phenolic and Alkaloid Contents Phenolic Content Analysis}

The phenolic content was analysed using FolinCiocalteau reagent (FCR) as described (22). The method is colorimetric method, based on chemical reduction of reagent mixture containing tungsten and molybdenum. To the extract $(\mathrm{mg} / \mathrm{ml})$ added FCR $(5 \mathrm{ml})$ and after the $30 \mathrm{~min}$ incubation time, color (blue) of the reaction mixture measured at $760 \mathrm{~nm}$, presence of phenolic content will enhance the absorbance and was calculated against the standard graph of gallic acid and expressed as gallic acid equivalents $(\mathrm{mg} / \mathrm{g})(21)$. The results were showed as mean \pm SEM $(n=3)$.

\section{Alkaloid Content Analysis}

The alkaloid contents of selected plant extracts were quantified by spectroscopic method (23) using bromocresol green (BCG) solution. The procedure was, to $1 \mathrm{ml}$ plant extracts dissolved in $2 \mathrm{~N}$ hydrochloric acid $(\mathrm{mg} / \mathrm{ml})$ added $5 \mathrm{ml}$ BCG solution in a separation funnel and $5 \mathrm{ml}$ of phosphate buffer and mixed well. After, the complex formed was extracted (separated) in chloroform (5 ml). The absorbance of chloroform (yellow color) was measured at $470 \mathrm{~nm}$ against the standard graph atropine (21). The results were showed as mean $\pm \operatorname{SEM}(\mathrm{n}=3)$.

\section{In-vitro Antioxidant Activity}

The in-vitro antioxidant activity of selected plant extracts was evaluated on superoxide, hydroxy, 2,2-diphenyl-1-picrylhydrazyl (DPPH) (21) hydrogen peroxide $\left(\mathrm{H}_{2} \mathrm{O}_{2}\right)$ (24) free radicals and reducing antioxidant power using ferric ion (25). The extracts were dissolved in dimethyl sulphoxide (DMSO) for easy solubility. The experiments results were presented as mean \pm SEM. The percentage inhibition (PI) was calculated as $\mathrm{PI}=(\mathrm{A} 0-\mathrm{A} 1) / \mathrm{A} 0 \mathrm{X}$ 100 A0: Absorbance of control; A1: Absorbance of plant extract or/and Ascorbic acid. The 50\% inhibition of concentrations (IC50 values) were calculated as graph plotted with concentration on $\mathrm{X}$-axis and percentage inhibition on Y-axis.

\section{Superoxide Free Radical Scavenging Activity}

Superoxide free radical scavenging activity was assessed as per the method (26). This is a spectroscopic method, evaluating the absorbance of light at $560 \mathrm{~nm}$ of a solution containing generated superoxide free radicals' riboflavin with nitroblue tetrazolium (NBT) reduction of color with different concentrations of extracts (20-320 $\mu \mathrm{g} / 100$ $\mu \mathrm{l})$. The ascorbic acid was used as positive control and the values was measured against corresponding blank.

\section{Hydroxyl Free Radical Scavenging Activity}

Hydroxyl scavenging activity of selected plant extracts was carried out by the procedure described (27). The method involved, measuring the absorbance of thiobarbituric acid reactive substances at $532 \mathrm{~nm}$ from the reduction of generated hydroxyl radicals through Fenton reaction mixture $\left(\mathrm{Fe}^{2+} / \mathrm{EDTA} / \mathrm{H}_{2} \mathrm{O}_{2}\right.$ system). 


\section{DPPH Free Radical Scavenging Activity}

The DPPH free radical scavenging activity was measured using the standard procedure (28). The procedure was measuring absorbance of alcoholic DPPH $(0.004 \%)$ (blue color to yellow color) after the addition of $0.1 \mathrm{ml}$ of testing extracts/ascorbic acid at different concentrations $(20-320 \mu \mathrm{g} / 100 \mu \mathrm{l})$.

\section{Hydrogen peroxide Scavenging Activity}

$\mathrm{H}_{2} \mathrm{O}_{2}$ scavenging activity was measured using method described (29). The method is measuring absorbance of reaction mixture at $230 \mathrm{~nm}$ containing $0.1 \mathrm{ml}$ of plant extract, $0.3 \mathrm{ml}$ of $50 \mathrm{mM}$ phosphate buffer and $0.6 \mathrm{ml}$ of $2 \mathrm{mM} \mathrm{H}_{2} \mathrm{O}_{2}(24)$ against the blank.

\section{Reducing Antioxidant Power Assay}

The reducing antioxidant power of extracts was measured with spectroscopic method described using Trolox as standard drug (25). The method is measuring color complex absorbance at $593 \mathrm{~nm}$ for reduction power of extracts at different concentrations from $\mathrm{Fe} 3+$ (color less) to Fe2+ (blue color) against the blank.

\section{In-vivo Antioxidant Activity}

The In-vivo antioxidant activity was studied using albino Wistar rats of either sex weighing from 200$250 \mathrm{gm}$ around 60-90 day aged. During the course of study, animals were maintained under controlled conditions (12 hr light/dark cycle, $24 \pm 2{ }^{\circ} \mathrm{C}, 40-70 \%$ relative humidity) by supplying sufficient food and water. Prior to start antioxidant activity on animals, the extracts were tested for their toxicity as per Organization for Economic Co-Operation and Development (OECD) guidelines with 1000 and 2000 $\mathrm{mg} / \mathrm{kg}$ body weight orally on overnight fasting animals using four groups ( $n=6$ each group) and observed at regular intervals for any changes in animals such as skin, morbidity, aggressiveness, oral secretions, sensitivity, pain, respiratory problems and finally mortality. The animal studies were approved by institutional ethical committee of Santhiram Medical College and General Hospital (897/PO/RE/S/05/CPCSEA).

After toxicity study, animals were divided in to seven groups $(n=6)$. Group I served as control received distilled water $(0.5 \mathrm{ml})$, groups II to IV received ethyl acetate extract $(100-400 \mu \mathrm{g} / \mathrm{ml})$ and groups V to VII received hydroalcoholic extract (100$400 \mu \mathrm{g} / \mathrm{ml}$ ) of $A$. praemorsa for 21 days administered orally using metal oropharyngeal cannula. 24 hrs after last dosage, blood was collected from animals using direct cardiac puncture under isoflurane anaesthetic condition to get serum through centrifuge at $2500 \mathrm{rpm}$ for $15 \mathrm{~min}$. to measure lipid peroxidation, estimation of superoxide dismutase (SOD) and catalase activity $(30,31)$.

\section{Lipid Peroxidation}

Lipid peroxidation was determined as per the procedure by measuring the thiobarbutiric acid reactive substances (TBARS) and malonaldehyde (MDA) in serum (32). The procedure was, serum was deproteinized by addition of trichloroacetic acid and thiobarbutiric acid and added $0.1 \mathrm{ml}$ of testing extract and then mixture was heated for $30 \mathrm{~min}$. in water bath. After cooling the mixture was centrifuged at $2000 \mathrm{rpm}$ for $10 \mathrm{~min}$, the absorbance of the supernatant (TBARS) at $535 \mathrm{~nm}$ spectrophotometrically against blank. The concentration of TBARS was calculated using the molar extinction coefficient of malondialdehyde (1.56 $\times 105 \mathrm{~mol} / \mathrm{L} / \mathrm{cm}$ ) and results were expressed in $\mathrm{nmol} /$ $\mathrm{mg}$ of protein.

\section{Superoxide Dismutase (SOD) Estimation}

SOD activity was determined by the method by xanthine-xanthine oxidase system for production of superoxide flux and NBT for their production. The SOD was measured by degree of inhibition of enzyme activity after the addition of plant extracts against blank and results expressed as U/ml (33).

\section{Catalase Activity}

The catalase activity was carried using spectrophotometrically as per Atawodi method (34). The method was measure absorbance of hydrogen peroxide at $240 \mathrm{~nm}$ from a mixture contains serum, potassium phosphate buffer, $30 \mathrm{mM} \mathrm{H}_{2} \mathrm{O}_{2}$ and testing extracts against blank after $30 \mathrm{~min}$. incubation (34).

\section{Statistical Analysis}

The results of in-vivo activity were analyzed by OneWay Analysis of variance (ANOVA) with Dunnett's T3 multiple comparison with control group using GraphPad Prism 8.

\section{Results and Discussion}

\section{Phytochemical Analysis}

The phytochemical analysis of $A$. praemorsa extracts showed presence of different phytoconstituents in them. Both the extracts have dissimilarity (Table 1), and possess sterols, terpenoids, glycosides, flavonoids, tannins, alkaloids, carbohydrates, phenols and gave negative results for amino acids. Hydroalcoholic extracts gave positive results for saponins and oils but ethyl acetate extract gave negative results.

\section{Quantification of Phenolic and Alkaloid Contents}

Both the extracts gave positive results for the presence of phenolics and alkaloids. So, their contents were quantified using standard procedures. Among two extracts hydroalcoholic extract possess more contents than ethyl acetate extract (Table 2).

\section{In-vitro and In-vivo Antioxidant Activity}

The antioxidant potential of $A$. praemorsa extracts was evaluated using different free radicals and on animals by evaluated enzyme levels with standard methods. The results of current study found the extracts possess concentration dependent potentiality on reduction of free radicals and increases the antioxidant enzymes levels in the body. Both the extracts have variation in controlling free radical and difference in percentage of inhibition and IC50 values. Among two extracts APHAE showed better activity as compared to APEAE. 
Superoxide ion was a weak oxidant produced as one of the by-products during different biological metabolisms in the body (35). The produced

Table 1. Phytochemical Analysis of Acampe praemorsa

\begin{tabular}{lcc}
\hline \multirow{2}{c}{$\begin{array}{c}\text { Name of the } \\
\text { phytoconstituent }\end{array}$} & \multicolumn{2}{c}{ Name of the extract } \\
\cline { 2 - 3 } Steroids & + & Hydro-alcoholic \\
\hline Terpenoids & + & + \\
\hline Glycosides & + & + \\
\hline Saponins & - & + \\
\hline Flavonoids & + & + \\
\hline Tannins & + & + \\
\hline Carbohydrates & + & + \\
\hline Alkaloids & + & + \\
\hline Amino acids & - & - \\
\hline Oils & - & + \\
\hline Quinones & + & - \\
\hline Phenols & + & + \\
\hline$+=$ Present; -Absent & &
\end{tabular}

Table 2. Phenolic and alkaloid contents of Acampe praemorsa extracts

\begin{tabular}{ccc}
\hline Name of the & \multicolumn{2}{c}{ Name of the Extract } \\
\cline { 2 - 3 } Component $(\mathrm{mg} / \mathrm{g})$ & Ethyl Acetate & Hydroalcoholic \\
\hline Total phenols & $22.55 \pm 0.06$ & $26.80 \pm 0.51$ \\
\hline Total Alkaloids & $17.68 \pm 0.25$ & $20.59 \pm 0.22$ \\
\hline
\end{tabular}

superoxide anion in body is major precursor for production of different free radicals such as hydroxyl radicals (21). The APEAE and APHAE have showed high percentage inhibition on superoxide free radicals with $66.00 \pm 1.15$ and $73.67 \pm 1.20$ respectively along with ascorbic acid having $88.0 \pm 1.73$ percentage inhibition (Fig. 2) on produced superoxide ions in PMS/NADH-NBT system of current study $(26,36)$. The IC50 values were found to be $198.33 \mu \mathrm{g}, 131.98 \mu \mathrm{g}$ and $79.48 \mu \mathrm{g}$ (Table 3).

Hydroxyl free radical scavenging activity of selected extracts was evaluated by reduction of hydroxyl radical's generation in presence of iron through Fenton reaction $(27,37,38)$. The APEAE and APHAE extracts showed percentage inhibition at 320 $\mu \mathrm{g}$ on hydroxyl free radicals was $75.0 \pm 1.73$ and $61.0 \pm 1.53$ respectively (Fig. 3). The ethyl acetate showed more activity compared to hydro-alcoholic extract. The IC50 values of APEAE, APHAE and ascorbic acid were $135.63 \mu \mathrm{g}, 191.77 \mu \mathrm{g}$ and $73.36 \mu \mathrm{g}$ respectively (Table 3 ).

The DDPH free radical scavenging activity was evaluated by generating DPPH, which is a stable radical molecule can react with the proton donor from antioxidant molecules. Upon reaction color of violet will change to yellowish (39). The percentage inhibition of APEAE and APHAE extracts on reduction of DPPH free radicals was $60.0 \pm 1.15$ and $80.67 \pm 1.45$ respectively (Fig. 4). The hydroalcoholic extract have more activity than ethyl acetate extract. The IC50 values of APEAE, APHAE extracts and ascorbic acid were found to be $204.17 \mu \mathrm{g}, 115.21 \mu \mathrm{g}$ and $73.65 \mu \mathrm{g}$ respectively.

The hydrogen peroxide is one of major free radical which can damage cell membrane through its penetrating capability and is also precursor for hydroxyl radicals, which can initiate lipid peroxidation $(40,41)$. The tested extracts of $A$.

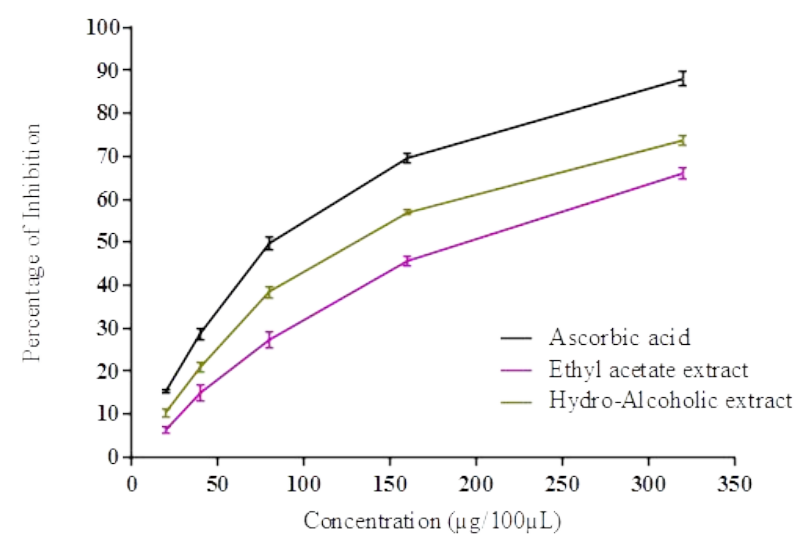

Fig. 2. In-vitro antioxidant activity of Acampe praemorsa extracts on superoxide free radicals.

Table 3. IC50 values of Acampe praemorsa extracts, Ascorbic acid and Trolox on different free radicals.

\begin{tabular}{lccccc}
\hline \multirow{2}{*}{$\begin{array}{c}\text { Name of the } \\
\text { extract/ } \\
\text { compound }\end{array}$} & \multicolumn{5}{c}{ IC50 Value ( $\mu g)$} \\
\cline { 2 - 6 } & $\begin{array}{c}\text { Super } \\
\text { oxide }\end{array}$ & $\begin{array}{c}\text { Hydro } \\
\text { xyl }\end{array}$ & DPPH & H$_{2} \mathbf{O}_{2}$ & $\begin{array}{c}\text { Reducing } \\
\text { power }\end{array}$ \\
\hline APEAE & 198.33 & 135.63 & 204.17 & 289.48 & 152.4 \\
\hline APHAE & 131.98 & 191.77 & 115.21 & 156.77 & 158.23 \\
\hline Ascorbic acid & 79.48 & 73.36 & 73.65 & 85.31 & N/AP \\
\hline Trolox & N/AP & N/AP & N/AP & N/AP & 72.19 \\
\hline
\end{tabular}

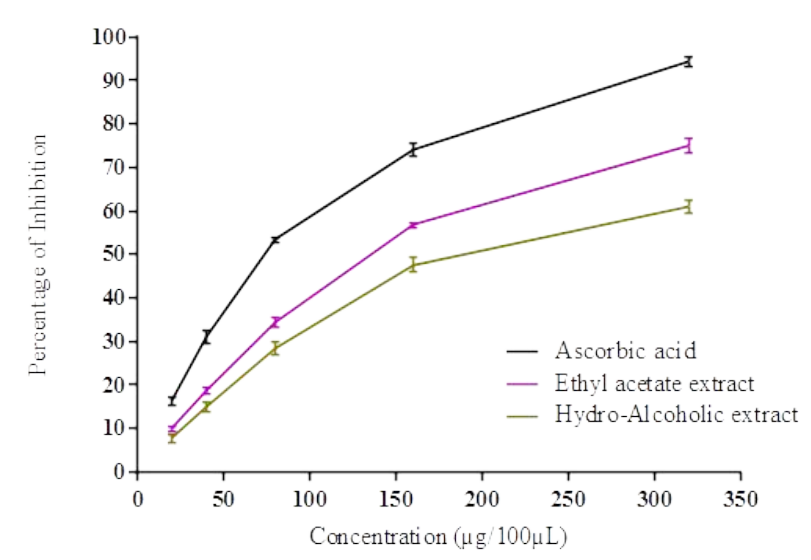

Fig. 3. In-vitro antioxidant activity of Acampe praemorsa extracts on hydroxyl free radicals.

praemorsa (APEAE and APHEA) showed concentration dependent percentage inhibition on produced $\mathrm{H}_{2} \mathrm{O}_{2}$ with percentage inhibition $54.00 \pm 1.73$ and $70.00 \pm 1.53$ at highest test concentration at $320 \mu \mathrm{g}$ (Fig. 5). The results are compared to standard drug ascorbic acid was less and the IC50 values were found to be 289.48 $\mu \mathrm{g}, 156.77 \mu \mathrm{g}$ and $85.31 \mu \mathrm{g}$ respectively (Table 3).

The reducing power assay of selected extracts (APEAE and APHEA) were carried on reduction of ferric ions to ferrous ions compared with standard drug Trolox (24). The extracts were found to possess concentration dependent activity with percentage inhibition $87.67 \pm 1.76$ and $81.00 \pm 1.73$ (Fig. 6). The IC50 values of APEAE, APHEA and Trolox were $152.4 \mu \mathrm{g}$, $158.23 \mu \mathrm{g}$ and $72.19 \mu \mathrm{g}$. Both the extracts had showed almost equal activity of reducing power (Table 3 ). 


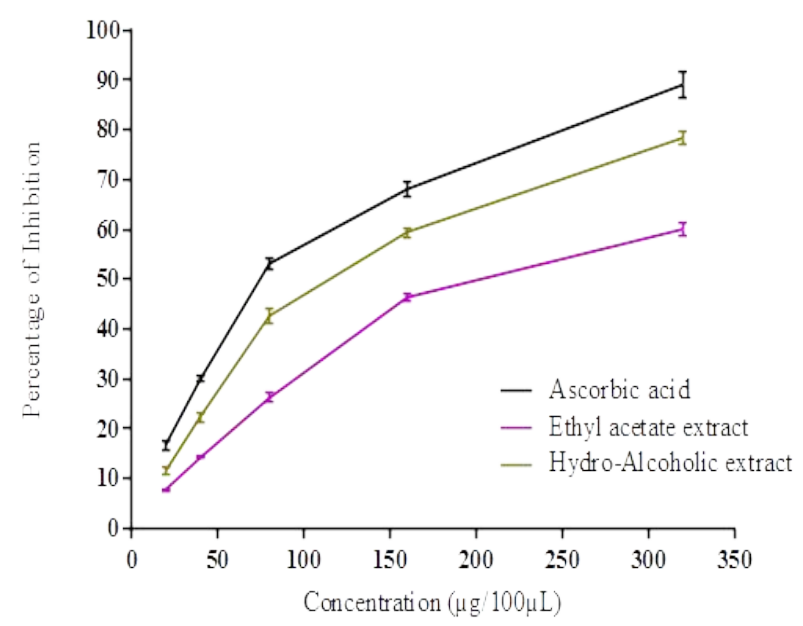

Fig. 4. In-vitro antioxidant activity of Acampe praemorsa extracts on DPPH free radicals.

The results of in-vitro antioxidant activity confirm presence of different antioxidant molecules in the selected plant extracts. So, in-vivo antioxidant activity studies were carried out evaluating oxidative enzymes

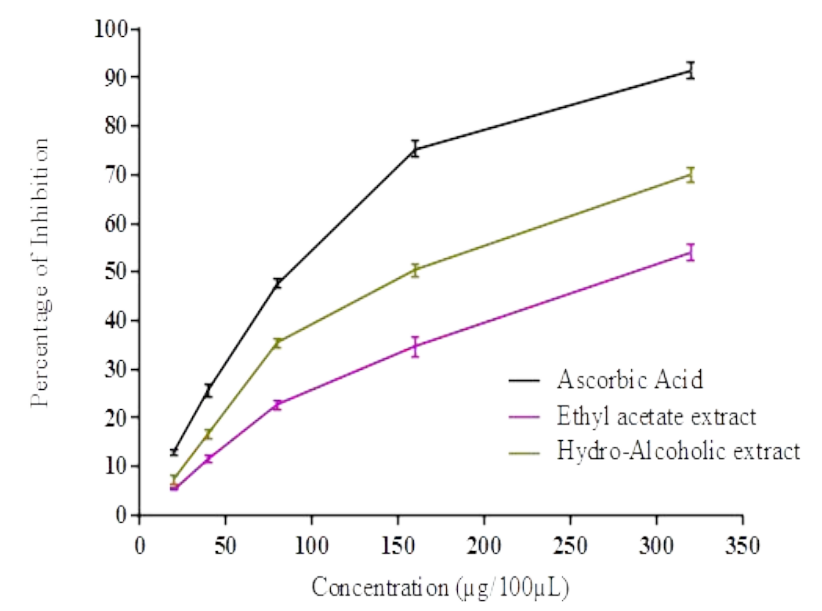

Fig. 5. In-vitro antioxidant activity of Acampe praemorsa extracts on hydrogen peroxide.

levels such as catalase, superoxide dismutase and malonaldehyde compound by lipide peroxidation. Before, proceeding the in-vivo study, the extracts were tested for toxicity and are found to be safe at testing or higher dosages and no physical, psychological and mortalities were observed.

The enzymatic levels of catalase, superoxide dismutase and malonaldehyde compound indicate the oxidative damage in the body through reactive oxygen species/free radicals. The catalase is a heme containing enzyme that can defend the cells in the body form different hydrogen peroxide by converting them into water and molecular oxygen $(31,42)$. SOD is a major enzyme that can dismutase the superoxide radicals into water and molecular oxygen (43). The results of current study in estimation of catalase SOD show that there is increase in levels of catalase and SOD than control group (Table 4) indicates the tested

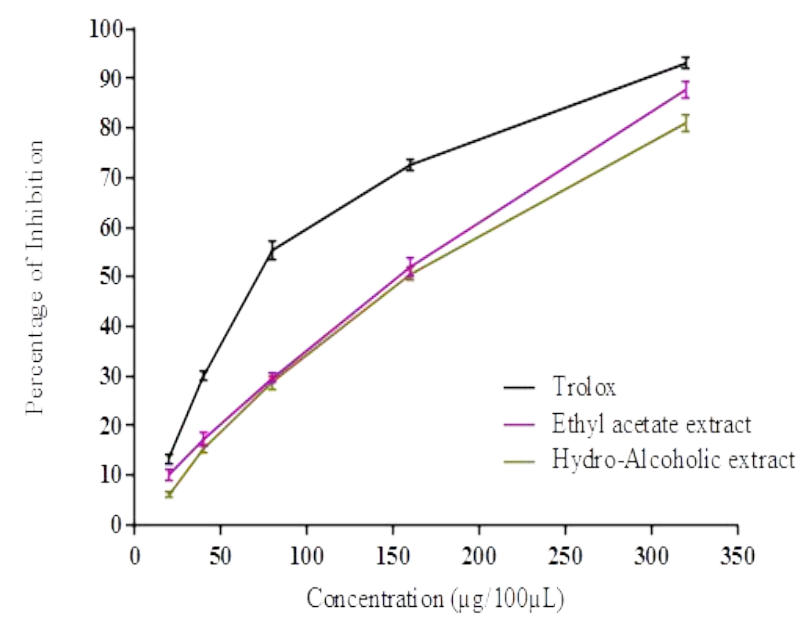

Fig. 6. In-vitro antioxidant activity of Acampe praemorsa extracts using reducing power assay.

extracts effectively increase levels of them and reduced the free radical's production.

Malonaldehyde (MDA) is a genotoxic compound produced in the body due to increased levels of lipid peroxidation (44). Lipid peroxidation is major damage in body due to the over production of free radical and reaction with cellular membrane and cause damage to deoxy ribonucleic acid (DNA) and changes in activities of membrane bound enzymes in different organs of the body (45). So, the levels of TBARS as production of MDA can indicate the controlling of free radical in the body. In the current study, level of MDA is less compared to the control group (Table 4) indicate that the extracts effectively reduce free radicals in the body and controlled the lipid peroxidation. The extracts of $A$. praemorsa exhibited concentration dependent control on enzymatic levels in the body in different groups. The hydroalcoholic extract at $400 \mathrm{mg} / \mathrm{kg}$ showed better activity compared to ethyl acetate extract.

The present study was aimed for phytochemical analysis and evaluation of antioxidant activity of $A$. praemorsa extracts. The results show that, there was variation in the phytochemical constituents in them and difference in controlling the free radicals and enzyme levels in the body. The researchers around world are successfully reporting biologically active compounds from natural resources $(46,47)$. Among them medicinal plants have been playing important role (10). In recent times, many researches have been reported biological activities and bioactive molecules from different medicinal plants $(5,48)$. In the current study, the phytochemical analysis of $A$. praemorsa extracts showed presence of bioactive molecules in them such as alkaloids, phenols, steroids etc. There were earlier reports on different medicinal plants containing alkaloids $(49,50)$ and phenols (51) with antioxidant potentiality and the results of present study confirms that $A$. praemorsa extracts had reduction of free radicals' generation and controlling of oxidative enzymes in the body. Among two extracts, hydroalcoholic extracts have more phenolic and alkaloid contents as well as it had showed more potentiality against free radicals and enzyme controlling. 
Table 4. Enzymatic levels in different groups due to the effect of Acampe praemorsa extracts at different doses.

\begin{tabular}{|c|c|c|c|}
\hline \multirow{2}{*}{$\begin{array}{c}\text { Name of the } \\
\text { extract/compound }\end{array}$} & \multicolumn{3}{|c|}{ Name of the enzyme/compound } \\
\hline & $\begin{array}{c}\text { Catalase } \\
(\mu \mathrm{mol} / \mathrm{mg} \text { protein })\end{array}$ & $\begin{array}{c}\text { MDA } \\
\text { (nmol/mg protein) }\end{array}$ & $\begin{array}{c}\text { SOD } \\
\text { (unit/mL) }\end{array}$ \\
\hline Control & $20.83 \pm 0.95$ & $0.103 \pm 0.03$ & $11.05 \pm 0.28$ \\
\hline APEAE $100 \mathrm{mg} / \mathrm{Kg}$ & $24.67 \pm 0.71^{\mathrm{ns}}$ & $0.104 \pm 0.001^{\mathrm{ns}}$ & $14.73 \pm 0.17$ \\
\hline APEAE $200 \mathrm{mg} / \mathrm{Kg}$ & $40.67 \pm 0.88^{*}$ & $0.085 \pm 0.002^{*}$ & $18.87 \pm 0.33$ \\
\hline APEAE $400 \mathrm{mg} / \mathrm{Kg}$ & $84.5 \pm 1.84^{*}$ & $0.063 \pm 0.001^{*}$ & $25.08 \pm 0.26^{* *}$ \\
\hline APHAE $100 \mathrm{mg} / \mathrm{Kg}$ & $29.17 \pm 0.48^{\mathrm{ns}}$ & $0.099 \pm 0.001^{\mathrm{ns}}$ & $15.99 \pm 0.06$ \\
\hline APHAE $200 \mathrm{mg} / \mathrm{Kg}$ & $47.17 \pm 1.30^{*}$ & $0.08 \pm 0.001^{*}$ & $21.7 \pm 0.40$ \\
\hline APHAE $400 \mathrm{mg} / \mathrm{Kg}$ & $95.67 \pm 1.20^{* *}$ & $0.061 \pm 0.001^{*}$ & $28.07 \pm 0.65^{* *}$ \\
\hline
\end{tabular}

ns=Non-significant; ${ }^{*}=\mathrm{P}<0.05 ;{ }^{* *} \mathrm{P}<0.01$

\section{Conclusion}

The present study was aimed to the evaluation of phytochemicals and antioxidant activity of Acampe praemorsa (Roxb.) Blatt. \& McCann extracts. The results of current study provide the evidence that A. praemorsa have different phytoconstituents in them and is having potent antioxidant activity. The extracts showed concentration dependent activity and hydroalcoholic extracts have more activity than ethyl acetate extracts and also phenolic, alkaloids contents. The variation in their activity may be due to the presence of divergence in different phytochemical compounds or their synergistic effect. In conclusion, the study provides phytochemical information of $A$. praemorsa and scientific evidence of its antioxidant activity and its folklore medicinal use. Further research is required to isolate the pure bioactive compounds and evaluate their biological activities.

\section{Acknowledgements}

The author, U. Praveen Kumar would like express thanks to Santhiram Medical College and General Hospital for providing necessary facilities to complete in-vivo studies.

\section{Authors' contributions}

PK and KR designed current study, carried experimental work and data analysis. All authors, PK, $\mathrm{KR}, \mathrm{RR}, \mathrm{KU}$ and $\mathrm{YV}$ contributed in preparation of manuscript and drafting it.

\section{Conflict of interests}

The authors have none to provide.

\section{References}

1. Pan SY, Zhou SF, Gao SH, Yu ZL, Zhang SF, Tang MK et al. New perspectives on how to discover drugs from herbal medicines: CAM's outstanding contribution to modern therapeutics. Evidence-Based Complementary and Alternative Medicine. 2013;627375. https://doi.org/10.1155/2013/627375

2. Su N, Yang J, Xie Y, Du X, Chen H, Zhou H et al. Bone function, dysfunction and its role in diseases including critical illness. International Journal of Biological Sciences. 2019;15(4):776-87. https://doi.org/10.7150/ijbs.27063

3. Harrison D, Kathy KG, Hornig B, Drexler H. Role of oxidative stress in atherosclerosis. American Journal of Cardiology. 2003;91:7A11A. https://doi.org/10.1016/s0002-9149(02)03144-2

4. Diplock T, Charleux JL, Crozier-Willi G, Kok FJ, Rice-Evans C, Roberfroid $\mathrm{M}$ et al. Functional food science and defence against reactive oxidative. British Journal of Nutrition. 1998;80(1):S77S112. https://doi.org/10.1079/bjn19980106

5. Sevindik M. Phenolic Content, Antioxidant and antimicrobial potential of Melanoleuca melaleuca edible mushroom. Journal of Animal and Plant Sciences. 2021;31(3):824-30. https://doi.org/10.36899/JAPS.2021.3.0272

6. Sikder MAA, Rahman MA, Islam MR, Abul KM, Kiasar MA Rahman MS. In-vitro antioxidant, reducing power, free radical scavenging and membrane stabilizing activities of Spilanthes calva. Bangladesh Pharmaceutical Journal. 2010;13:63-67.

7. Talluri MR, Ketha A, Battu GR, Tadi RS, Tatipamula V. Protective effect of Aurelia aurita against free radicals and streptozotocininduced diabetes. Bangladesh Journal of Pharmacology. 2018;13(3):287-95. https://doi.org/10.3329/bjp.v13i3.36907

8. Huang, D. Dietary antioxidants and health promotion. Antioxidants (Basel). 2018;7(1):1-3. https://doi.org/10.3390/antiox7010009

9. Wilson DW, Nash P, Buttar HS, Griffiths K, Singh R, De Meester F et al. The role of food antioxidants, benefits of functional foods and influence of feeding habits on the health of the older persons: An $\begin{array}{llll}\text { overview. } & \text { Antioxidants } & \text { (Basel). 2017;6(4):81. }\end{array}$ https://doi.org/10.3390/antiox6040081

10. Altemimi A, Lakhssassi N, Baharlouei A, Watson DG, Light-foot DA Phytochemicals: Extraction, isolation and identification of bioactive compounds from plant extracts. Plants (Basel). 2017; 6(4):1-23. https://doi.org/10.3390/plants6040042

11. Mouhssen L. The success of natural products in drug discovery Pharmacology and Pharmacy. 2013;4:17-31. https://dx.doi.org/10.4236/pp.2013.43A003

12. Piddock LJ. The crisis of no new antibiotics-what is the way forward? Lancet. Infectious Diseases. 2012;12(3):249-53. https://doi.org/10.1016/S1473-3099(11)70316-4.

13. Shi QW, Li LG, Huo CH, Zhan ML, Wang YF. Study on natural medicinal chemistry and new drug development. Chinese Traditional and Herbal Drugs. 2010;41:1583-89. https://doi.org/10.4103/0974-8520.100295

14. Raghuveer C, Tandon RV. Consumption of functional food and our health concerns. Pakistan Journal of Physiology. 2009;5:76-83.

15. Maridass M, Zahir Hussain MI, Raju G. Phytochemical survey of orchids in Tirunelveli hills of South India. Ethnobotanical Leaflets. 2008;12:705-12.

16. Dash PK, Sahoo S, Bal S. Ethnobotanical studies on orchids of Niyamgiri hill ranges, Orissa, India. Ethnobotanical Leaflets. 2008;12:70-78.

17. Pullaiah, T. Encyclopaedia of World Medicinal plants. Vol.1. Regency Publications, New Delhi (India). 2006;33.

18. Reddy KN, Subbaraju GV, Reddy S. Ethnobotany of certain orchids of eastern ghats of Andhra Pradesh. EPTRI-ENVIS Newsletter. 2005;11:5.

19. Bulpitt CJ. The uses and misuses of orchids in medicine. QJM. 2005; 8: 625-31. https://doi.org/10.1093/qjmed/hci094

20. Trease G, Evans SM. Pharmacognosy. 15th ed. Bailer Tindal, London, Elsevier Publisher. 2002;23-67.

21. Rao BG, Rao YV, Rao TM. Hepatoprotective and antioxidant capacity of Melochia corchorifolia extracts. Asian Pacific Journal of 
Tropical Medicine. 2013;6:537-43. https://doi.org/10.1016/S19957645(13)60092-9

22. Singleton VL, Rossi JA. Colorimetry of total phenolics with phosphomolybdic acid phosphotungstic acid reagents. American Journal of Enology and Viticulture. 1965;16:144-58.

23. Shamsa F, Hamidreza $M$, Rouhollah $G$, Verdian-rizi $M$. Spectrophotometric determination of total alkaloids in some Iranian medicinal plants. Thai Journal of Pharmaceutical Sciences. 2008;32:17-20

24. Bhatti MZ, Ali A, Ahmad A, Saeed A. Malik SA. Antioxidant and phytochemical analysis of Ranunculus arvensis L. extracts. BMC Research Notes. 2015;8:279. https://doi.org/10.1186/s13104-0151228-3

25. Benzie IF, Strain JJ. The ferric reducing ability of plasma (FRAP) as measurement of "antioxidant power" The FRAP assay. Analytical $\begin{array}{lll}\text { Biochemistry. } & \text { 239:70-76. }\end{array}$ https://doi.org/10.1006/abio.1996.0292.

26. Mc Cord JM, Fridovich I. Superoxide dismutase: An enzymic function for erythrocuprein (hemocuprien). Journal of Biological Chemistry. 1969;244:6049-55.

27. Elizabeth K, Rao MNA. Oxygen radical scavenging activity of curcumin. International Journal of Pharmaceutics. 1990;58:237-40.

28. Braca A, Fico G, Morelli I, de Simone F, Tome F, de Tomnasi N. Antioxidant and free radical scavenging activity of flavonol glycosides from different Aconitum spp. Journal of Ethnopharmacology. 2003;86:63-67. https://doi.org/10.1016/S03788741(03)00043-6

29. Ruch RJ, Cheng SJ, Klaunig JE. Prevention of cytotoxicity and inhibition of intercellular communication by antioxidant catechins isolated from Chinese green tea. Carcinogenesis. 1989;10:1003-08. https://doi.org/10.1093/carcin/10.6.1003

30. Onoja SO, Omeh YN, Ezeja MI, Chukwu MN. Evaluation of the in vitro and in vivo antioxidant potentials of Aframomum melegueta methanolic seed extract. Journal of Tropical Medicine. 2014;159343. https://doi.org/10.1155/2014/159343

31. Malomo SO, Ore A, Yakubu MT. In vitro and in vivo antioxidant activities of the aqueous extract of Celosia argentea leaves. Indian $\begin{array}{lll}\text { Journal of Pharmacology. 2011;43(3):278-85. } & \end{array}$ https://doi.org/10.4103/0253-7613.81519

32. Draper HH, Hadley M. Malondialdehyde determination as index of lipid peroxidation. Methods. Enzymology. 1990;186:421-31. https://doi.org/10.1016/0076-6879(90)86135-i

33. Sun Y, Oberley LW, Li Y. A simple method for clinical assay of superoxide dismutase. Clinical Chemistry. 1988;34(3):497-500.

34. Atawodi SE. Evaluation of the hypoglycaemic, hypolipidemic and antioxidant effects of methanolic extract of "Ata-Ofa” polyherbal tea (A-polyherbal) in alloxan-induced diabetic rats. Drug Invention Today. 2011;3:270-76.

35. Ebrahimzadeh MA, Nabavi SF, Nabavi SM. Antioxidant activities of methanol extract of Sambucus ebulus L. flower. Pakistan Journal of Biological Sciences. 2009; 12(5):447-50. https://doi.org/10.3923/pjbs.2009.447.450

36. Toda S, Ohnishi M, Kimura M, Nakashima K. (1988). Action of curcuminoids on the hemolysis and lipid peroxidation of mouse erythrocytes induced by hydrogen peroxide. Journal of Ethnopharmacology. https://doi.org/10.1016/0378-8741(88)90119-5

37. Chung SK, Osawa T, Kawakishi S. Hydroxyl radical scavenging effects of spices and scavengers from brown mustard (Brassica nigra). Bioscience, Biotechnology and Biochemistry. 1997;61:11823. https://doi.org/10.1271/bbb.61.118

38. Adjimani JP, Asare P. Antioxidant and free radical scavenging activity of iron chelators. Toxicology Reports. 2015;2:721-28. https://doi.org/10.1016/j.toxrep.2015.04.005

39. Dehpour AA, Ebrahimzadeh MA, Seyed Fazel NSeyed Mohammad N. Antioxidant activity of the methanol extract of Ferula asafoetida and its essential oil composition. Grasas Y Aceites. 2009;60(4):40512. https://doi.org/10.3989/gya.010109

40. Fernando CD, Soysa P. Optimized enzymatic colorimetric assay for determination of hydrogen peroxide $\left(\mathrm{H}_{2} \mathrm{O}_{2}\right)$ scavenging activity of plant extracts. MethodsX.

2001;2:283-91

https://doi.org/10.1016/j.mex.2015.05.001

41. Sasikumar V, Kalaisezhiyen P. Evaluation of free radical scavenging activity of various leaf extracts from Kedrostis foetidissima (Jacq.) Cogn. Food Science and Human Wellness. 2014; 3: 150. https://doi.org/10.1016/j.fshw.2015.02.001

42. Kohen R, Nyska A. Oxidation of biological systems: oxidative stress phenomena, antioxidants, redox reactions and methods for their quantification. Toxicologic Pathology. 2002;30:(6):620-50. https://doi.org/10.1080/01926230290166724

43. Dorman HJ, Koşar M, Kahlos K, Holm Y, Hiltunen R. Antioxidant properties and composition of aqueous extracts from Mentha species, hybrids, varieties and cultivars. Journal of Agricultura and Food Chemistry. 2003;51:(16):4563-69. https://doi.org/10.1021/jf034108k

44. Bakirel T, Bakirel U, Keleş OÜ, Ülgen SG, Yardibi H. In vivo assessment of antidiabetic and antioxidant activities of rosemary (Rosmarinus officinalis) in alloxan-diabetic rabbits. Journal of $\begin{array}{llr}\text { Ethnopharmacology. } & \text { 2008; } & \text { 116(1): }\end{array}$ https://doi.org/10.1016/j.jep.2007.10.039

45. Niedernhofer LJ, Daniels JS, Rouzer CA, Greene RE, Marnett LJ Malondialdehyde, a product of lipid peroxidation, is mutagenic in human cells. Journal of Biological Chemistry. 2003;278:(33):31426 33. https://doi.org/10.1074/jbc.M212549200

46. Singh YD, Jena B, Ningthoujam R, Panda S, Priyadarsini P, Pattanayak S, Panda MK, Singh MC, Satapathy KB. Potentia bioactive molecules from natural products to combat against coronavirus. Advances in Traditional Medicine. 2020;1-12. https:// doi.org/10.1007/s13596-020-00496-W

47. Mukherjee PK, Maity N, Nema NK, Sarkar BK. Bioactive compounds from natural resources against skin aging. Phytomedicine. https://doi.org/10.1016/j.phymed.2011.10.003

2011;19(1):64-73.

48. Unuofin JO, Lebelo SL. Antioxidant effects and mechanisms of medicinal plants and their bioactive compounds for the prevention and treatment of Type 2 diabetes: An updated review. Oxidative Medicine and Cellular Longevity. 2020; 1356893. https:// doi.org/10.1155/2020/1356893

49. Tonisi S, Okaiyeto K, Hoppe H, Mabinya LV, Nwodo UU, Okoh AI. Chemical constituents, antioxidant and cytotoxicity properties of Leonotis leonurus used in the folklore management of neurological disorders in the Eastern Cape, South Africa. 3 Biotech 2020;10(3):141. https://doi.org/10.1007/s13205-020-2126-5

50. Pandey BP, Adhikari K, Pradhan SP, Shin HJ, Lee EK, Jung HJ. Invitro antioxidant, anti-cancer and antiinflammatory activities of selected medicinal plants from western Nepal. Future Journal of $\begin{array}{llll}\text { Pharmaceutical } & \text { Sciences. } & \text { 2020; } & \end{array}$ https://doi.org/10.1186/s43094-020-00107-0

51. Ferreira-Santos P, Zanuso E, Genisheva Z, Rocha CMR, Teixeira JA Green and sustainable valorization of bioactive phenolic compounds from Pinus by-products. Molecules. 2020;25(12):2931. https://doi.org/10.3390/molecules25122931

\section{Additional information}

Peer review information: Plant Science Today thanks Sectional Editor and the other anonymous reviewers for their contribution to the peer review of this work.

Reprints and permissions information is available at

https://horizonepublishing.com/journals/index.php/PST/open_access_policy

Publisher's Note: Horizon e-Publishing Group remains neutral with regard to jurisdictional claims in published maps and institutional affiliations.

To cite this article: Kumar U P, Rao G S N K, Reddy A R, Umasankar K, Vangoori Y. Protective effect of Acampe praemorsa (Roxb.) Blatt. \& McCann against oxidative stress. Plant Science Today. 2021;8(3):552-558.

https://doi.org/10.14719/pst.2021.8.3.1207

Plant Science Today, published by Horizon e-Publishing Group, is covered by Scopus, Web of Science, BIOSIS Previews, Clarivate Analytics, etc. See https://horizonepublishing.com/journals/index.php/PST/indexing_abstracting 